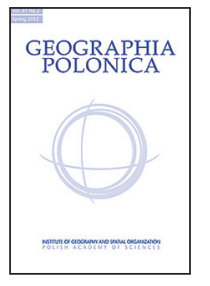 \\ INSTITUTE OF GEOGRAPHY AND SPATIAL ORGANIZATION \\ POLISH ACADEMY OF SCIENCES \\ www.igipz.pan.pl \\ www.geographiapolonica.pl
}

\title{
IS THE SUBURBANISATION STAGE ALWAYS IMPORTANT IN THE TRANSFORMATION OF LARGE URBAN AGGLOMERATIONS? THE CASE OF THE KATOWICE CONURBATION
}

\section{Robert Krzysztofik • Iwona Kantor-Pietraga • Anna Runge • Tomasz Spórna}

Departament of Economic Geography

University of Silesia

Będzińska 60, 41-200 Sosnowiec: Poland

corresponding Author, e-mail: robert_krzysztofik@interia.pl

\begin{abstract}
Suburbanisation represents one of the most important contemporary problems facing large urban agglomerations. An analysis of the development of urban agglomerations in Central-Eastern Europe, and especially Poland, leads to the observation that this problem is not particularly advanced in any of them. The aim of this article has thus been to examine how relevant it might be to consider the suburbanisation stage in large Polish agglomerations, as a permanent feature of the Klaassen/Paelinck and van den Berg models. Specifically, the article focuses on Poland's seven largest agglomerations, though there is a particular emphasis on the Katowice conurbation. The essence of the study lay in the identification of differences in the population balance between these agglomerations, and above all, between their cores and outer zones. The study also included data on the structure characterising out-migrations. A consequence of the study was to draw attention to the apparent diversity of the Katowice conurbation, the only one in Poland to record a population decline in both the core area and the outer zone. This specificity was explained mainly by the drivers of polycentricity and post-industrialism. In other agglomerations, these elements were either absent altogether or were involved in separate shaping of urban regional space.
\end{abstract}

\section{Key words}

suburbanisation • urban agglomeration • postindustrial region • urban polycentrism • Central-Eastern Europe 


\section{Introduction}

Spatial redistribution of the population, including the phenomenon of suburbanisation, represents one of the basic elements influencing the specificity of socio-economic processes over large urban regions of Europe (Scott 2001; EU 2006; Couch et al. 2007). This results, not only from marked demographic potential, but also from the role these regions play in national and global network connectivity. However, previous studies on this issue have shown that spatial redistribution of population does not follow the same patterns even in metropolitan regions of similar genesis, population and geographical location (Nicolaides \& Wiese 2006; Kabisch \& Haase 2011; Ravetz et al. 2013; Stanilov \& Sýkora 2014; Hoekveld 2015; Rubiera Morollón et al. 2016). Urban agglomerations not only have different trajectories where changes in population are concerned (Turok \& Mykhnenko 2007; Kabisch et al. 2012; Rubeira et al. 2015), but they also manifest different conditions for, and levels of development of, such phenomena as suburbanisation, depopulation, or territorial development resulting from population growth.

A good case in point would be the process as it is to be noted in certain post-communist European countries. Even in the late 1980s and early 1990s, a relatively strong resemblance between large cities in terms of demographic development was to be observed there, both within individual countries as well as across the whole region of post-communist Central and Eastern Europe (Pichler-Milanović et al. 2007; Steinführer \& Haase 2007; Stanilov \& Sýkora 2014). In looking for a suitable model to describe spatial redistribution of the population in metropolitan areas of this region in the period up to 1990, it would be most appropriate to refer to the stage of urbanisation in the model of Klaassen and Paelinck (1979), or else the stage of absolute centralisation in the van den Berg model (van den Berg et al. 1982). The essence of these phenomena in spatial terms is rapid population growth in urban cores with a relatively low rate of suburbanisation, especially in areas with poor accessibility as regards transport. Suburbanisation in Central and Eastern Europe was certainly hampered by a low index of motorisation in the population. For example, in Poland only 4.5 million cars were registered in 1989, as compared with as many as 25 million in 2014 (CSO 1990, 2015).

The rapid (1989-1990) collapse of the existing basis for development in Eastern European cities, as based on communist-era political and economic conditions, forced significant changes in the spatial distribution of the population (Musil 1993; Sailer-Fliege 1999; Śleszyński 2006; Mykhnenko \& Turok 2008; Schmidt 2011; Sýkora \& Bouzarovski 2012; Schmidt et al. 2015). While the course of urbanisation until the 1990s had alluded to the stage of urbanisation in the Klaassen and Paelinck model, the next naturally expected stage would have been suburbanisation, which actually happened in most metropolises of Central and Eastern Europe, including for example Prague, Budapest, Warsaw and some others (Pichler-Milanović et al. 2007; Kabisch \& Hasse 2011; Stanilov \& Sýkora 2014).

It was the possibility of a model of transformation different from that proposed by Klasseen/Paelinck and van den Berg that encouraged various studies on the genetic determinants of suburbanisation (Gans 2000; Nuissl \& Rink 2005; Kabisch \& Haase 2011; Salvati \& Carlucci 2014).

In further seeking to confirm the thesis presented, the work detailed in this paper has involved analysis of large urban agglomerations in Poland that may further be seen as relatively representative urban regions when it comes to the demographic and socio-economic transformations taking place in Central and Eastern Europe as a whole, post-1990.

However, given that other factors have appeared, the demographic transformations in Central and Eastern European cities have been characterised by a visible dualism. On the one hand, there are large (more than 1 million-inhabitant) and fairly large (0.5-1 million-inhabitant) cities with surrounding suburbs in such cases as Moscow, Budapest, Warsaw, Prague, Bucharest, Sofia and Tallinn (Sýkora 
\& Ouředníček 2007; Ouředníček 2007; Leetmaa \& Tammaru 2007; Bajmócy 2012; Brade et al. 2009; Krišjāne \& Bērzinšs 2012; Cirtautas 2013; Lisowski et al. 2014). On the other hand, there have been cases of demographic transformation in major cities and agglomerations in which spatial suburbanisation has sometimes been insignificant in relative terms (when set against the size of the population), as in the case of Poland's Katowice conurbation with its more than 2 million inhabitants (Runge et al. 2011; Zborowski et al. 2012).

In this context, the aim of the work described here has been to address the twin issues of the attributes working directly to ensure the weakness of the suburbanisation process in a large urban region, as well as the dissonance between the idea that weak spatial suburbanisation causes weak urban shrinkage (given that the former is the most common cause of the latter) and the idea that weakness of suburbanisation may be a symptom of some far more dangerous phenomenon.

\section{Hypothesis}

Large cities with highly-specialised functions (such as mining, industry, or transport) represent a specific type of urban centre, given that their potential was mainly responsible for quantitative (demographic) development, with migrant inflow being of particular importance. The scale of this inflow may in fact ensure such rapid demographic development that the stage of suburbanisation is 'imposed' on that of urbanisation. In such cases, areas that might otherwise have been suburbia become an integral part of the city (often within a decade), with the strength of urban development causing further expansion beyond the urban core. Such a process is clearly visible in China's large cities at the present time (Ye Wu 2014).

In the cities of Central Europe, inter alia, phenomenon of this kind were reinforced in the post-War (1950-1989) period, as block housing-estates expanded peripherally, forming characteristic external wreaths of development. In such cases, the scale of suburbanisation in the context of population growth within the core was insignificant, while the secondary development of districts located beyond the rings of surrounding housing estates was much more explicit.

Things are different in cities experiencing a more-balanced impact of specialised and central functions, in which development occurs in waves. The spread of the core area to the exterior is here accompanied by an expansion of the suburbs, and the demographic development taking place is more harmonised and uniform. This is well presented in a model from P. Korcelli (1972) in which the wavelike progress of urban zone growth is made clear. In the outer zone, it was mostly low development that prevailed, given the important role of central functions reflected in geographical space by processes and phenomena that arrange and organise them. This was possible due to the relatively more limited scale of migration inflow, which in turn supplied better opportunities for concurrent spatial planning and the development of urban strategies.

The indicated functions of large cities and determined dynamics of population growth and distribution within the agglomeration constituted a key element stabilising urbanisation at this stage (in line with the Klaassen and Paelinck model). They also had a major influence on the specifics of urban demographic structures. A characteristic feature of Polish and most Central European cities in the years 1970-1985 was a rapid inflow of population aged 18-35. This was especially true of those cities whose development was stimulated by specialised functions like industry and mining (Parysek 2005; Sokołowski 2006; Maik 2009).

A high birth rate was a feature of an era in which the post-War baby-boom generation was entering its marriage years. The inflow of large numbers of young people to the cities, in which, in the context of the state of the communist era, they were guaranteed economic stability (work, housing, and social benefits), favoured an increase in the birth rate. Until the mid-1980s, the population aged 35 or less 
took an overwhelming share among all the inhabitants of such cities.

A further feature of large, extremely specialised cities and urban agglomerations was a demographic potential not in proportion with the functional role they played in surrounding regions. In Poland, the functional (economic) potential on a regional basis was already in place in the 1970s and 1980s, in the form of cities of 400-500 thousand (Poznań and Gdańsk). At the same time, certain cities and groups of core towns had achieved much greater population sizes (Łódź - 850 thousand inhabitants and the Katowice conurbation with as many as 2.5 million). Self-evidently, the population 'surplus' beyond approximately half a million inhabitants (to be noted in Łódź and the Katowice conurbation) indicated the role of the industrial specialisation factor. This was what stabilised development, rather than central functions of a regional nature performed (Sokołowski 2006). It was this development of large cities with a marked population 'surplus' that was confronted sharply by the new economic and socio-political reality after the changes of 1989 .

Deindustrialisation and a rapidly progressing deurbanisation led to rapid depopulation in the large metropolises with their 'surplus'. The population of Łódź is now down to just 700 thousand, and the decline is continuing rapidly (Marcińczak 2012). Demographic forecasts indicate that, by 2050, the population of that city will have stabilized at 450-500 thousand. A similar situation applies to the Katowice conurbation, whose population in the years 1990-2014 decreased by 300 thousand and currently amounts to 2.1 million inhabitants. The Central Statistical Office's demographic forecast for 2050 indicates that in another 35 years that population will have fallen to 1.4 million, with the decrease still progressing (CSO 2014). It is interesting that these two urban agglomeration with a large population 'surplus' in the communist era are characterized by a contemporary process of spatial suburbanisation that needs to be seen as relatively weak (Śleszyński 2011; Runge et al. 2014).
Where the thesis regarding the weakness of spatial suburbanisation in some urban regions is concerned, consideration should be given to the following sequence of socioeconomic and spatial phenomena.

In the first stage - of urbanisation, dynamically developing industry forced a rapid migration inflow. Strong population growth determined in line with the mono-functional economy of the urban agglomeration still did not satisfy the needs of growing industry, especially in the first development phase. The drawing power of the city was reflected in:

- efficient transport between the place of residence and the workplace,

- good availability of basic services and commerce,

- the fact that a significant proportion of the flats in block estates were allocated, and not sold, or else sold below their market value.

All these facilities amounted to real competition for suburban areas. In turn, in the latter were underinvested in in the communist era, and the level of motorisation in society was also low, ensuring that the possibilities for daily commutes to the city were limited. Finally, and equally importantly, the construction of new houses was difficult, for financial and organisational reasons, and in some periods also for supply reasons (difficulties with the purchase of construction materials). The suburbanisation phenomena that did exist in that period were mostly associated with railway lines, especially in places where suburban settlements had begun to grow even before World War II.

In the second stage - of deurbanisation, a sudden collapse of industry led to a highlighted phenomenon of urban depopulation. This process is mostly generated by migration outflow, with the participation of a mobile, and thus young, population. The result of this selective emigration is an increase in the percentage of the population that is of postworking age, i.e. pensioners, for whom the post-industrial regions represent relatively good places to live, especially if a person has anyway spent the majority of his/her life there. 
However, in the longer term, such changes in the age structure of the population (population ageing) lead to a steady decrease in birth rates that only exacerbates the depopulation process.

Deindustrialisation of a polycentric urban region whose development has thus far been based on industrial or mining functions, with relatively limited development of specialised services and manufacturing of the R\&D sector, do not constitute good conditions for ongoing suburbanisation. In contrast, what does encourage it are factors such as strong growth of the automotive industry, greater spatial mobility of the population, or the individualisation of social life. However, compared with monocentral urban regions with more diversified economies, this one only has relatively weal suburbanisation.

Therefore, with reference to the Klasseen/ Paelinck and van den Berg's models, we propose two transformation paths in the evolution of large cities:

1. urbanisation - suburbanisation - deurbanisation, and

2. urbanisation - deurbanisation ${ }^{1}$.

Of course, depending on the case, both models allow for the possibility of a re-urbanisation phase. An example of an urban region whose transformation should be interpreted in line with the second model is the Katowice conurbation in Poland.

\section{Data and methods}

The aim of the article is to draw attention to the specificity of the suburbanisation stage in one large urban agglomeration population of Central or Eastern Europe - the Katowice conurbation in Poland. Research on this issue has focused on two depictions of this problem - one comparative and one structural.

In the first depiction, the phenomenon of suburbanisation in the subject region

\footnotetext{
1 In this case, the deurbanisation shown should be explained by reference to the model of urban shrinkage, which takes in economic, demographic, social, spatial, infrastructural and local policy elements as background to the final effect of deurbanisation in a region.
}

is compared with other selected urban agglomerations in Poland. From a methodological point of view, the problem addressed here is complex, due to there being different definitions of the limits of suburban areas, as well as a need to consider whether a suburbanisation zone is determined by the number of people living in it (suburbanisation as a state) or by the activity of those migrating there over a certain period of time (suburbanisation as a process). This article attempts to connect these depictions.

Finally, to research the significance of suburbanisation, use is made of the criterion of population change in core and suburban areas of the agglomerations analysed. Such a broad approach allows particular agglomerations to be compared without profound additional explanation or reference to local circumstances, this not being the ultimate goal of the article, other than in regard to Katowice. The core of urban agglomerations is deemed confined to towns with a county status, as well as some included in the core zone where the official delimitation of Polish agglomerations is concerned (Śleszyński 2011). The suburban zone is defined in relation to counties surrounding the urban core. There are many other possible delimitations of the suburban zone, but each presents a different division and range. We therefore decided upon the administrative criterion important from the statistical point of view.

This article presents the population balance for two 20-year periods. The first, in the communist era, was nevertheless the time of an initial socio-economic transformation (1975-1995), while the second period saw that transformation advance- in the years 19952014. It was assumed that the diversity associated with the social, political and economic transformation would have a significant influence on the development of large agglomerations in line with the Klaassen/Paelinck and van den Berg models.

However, resort to a comparative approach does not address the issue of the structure characterising population movements. Theoretically, strong growth dynamics 
in a suburban zone may be accompanied by an even more marked trend for migration to other regions of the country or abroad to take place. Hence, in structural terms, a detailed analysis of the components to the immigration process was attempted, the preliminary assumption being that suburbanisation derives mainly from inflow from the cores of cities to their suburban areas. In the municipalities of the Katowice Conurbation, such inflows were in the range $82-98 \%$ in the years 1999-2013. This was also the prevalent situation in other large Polish cities.

To determine the structure characterising migration outflow, the types of population movement were:

- within the core of a conurbation (from a city to a city).

- from the core of a conurbation to its suburban zone,

- from the core of a conurbation to other Polish regions,

- from the core of a conurbation to other countries.

The elementary database consisted of information obtained from the Central Statistical Office in Warsaw on de-registrations of residents from the studied urban region. The database contained available data on population movements in every urban area located in the core to other cities and municipalities in Poland and abroad. The data were aggregated so as to supply information about the above types of population movements in the years 1999-2011. In addition, information about movements between particular towns and cities of the Katowice conurbation was also included. A similar procedure was applied to the remaining six urban agglomerations; of Gdańsk, Kraków, Łódź, Poznań, Warsaw and Wrocław.

The dynamics for the populations of all of these urban areas were defined in relation to differences in their population during the periods 1976-1995 and 1995-2014. These dynamics were indicated for the urban region as a whole, its core and also the suburban zone, as a matter of particular interest here.

\section{Results}

Research into the demographic aspect of suburbanisation in Polish agglomerations points to the specific nature of this phenomenon in the case of the Katowice conurbation (Śleszyński 2014; Runge et al. 2014). In general, the differences characterising the spatial redistribution of the population here are in line with factors identified in the Hypothesis part of this article. Nevertheless, the final results as regards the phenomena discussed are interesting.

All urban cores in Poland experienced population growth in the communist era, though this was greatest in Warsaw and Poznań. The rather more limited population increase experienced by the Katowice conurbation resulted from initial features of a depopulation that had become tangible by the next period (at least in Chorzów). The agglomeration cores displaying the most limited increase in population were those of Poznań and Wrocław. At the same time, the population increase in the outer zones of all agglomerations was also more limited than in the core areas. As Table 1 and Figure 1 make clear, this trend reversed in the 1995-2014 period, with the outer zones of all agglomerations sowing a larger population increase, or at least a more limited decline (in the case of the Katowice conurbation). It was thus clear that the focus in the urban regions under analysis had shifted beyond their cores.

The attention is also drawn to the relatively limited suburbanisation in the Katowice conurbation in comparison with others in Poland, especially given the region's demographic potential. In the years 1999-2013, the suburban zone of the Katowice conurbation was the only one in Poland to report a population decline (Tab. 1). Indeed, this was the only urban agglomeration of this size anywhere in Central and Eastern Europe to experience no population growth in its suburban zone (Stanilov \& Sýkora 2014). Thus, the suburban areas of all other agglomerations witnessed an increase in population, that was even accompanies by an increase in the number of core-area 
Is the suburbanisation stage always important in the transformation of large urban...

Table 1. Changes of population size in Poland's agglomerations, 1976-2014

\begin{tabular}{|c|c|c|c|c|c|c|c|c|}
\hline \multirow{3}{*}{ Agglomeration } & \multicolumn{2}{|c|}{$\begin{array}{l}\text { Trend } \\
\text { for the population } \\
\text { in the suburban zone }\end{array}$} & \multicolumn{2}{|c|}{$\begin{array}{c}\text { Trend } \\
\text { for the population } \\
\text { in the core }\end{array}$} & \multicolumn{2}{|c|}{$\begin{array}{l}\text { Overall } \\
\text { change }\end{array}$} & \multirow{3}{*}{$\begin{array}{l}\text { Post- } \\
\text { industrial } \\
\text { region? }\end{array}$} & \multirow{3}{*}{$\begin{array}{l}\text { Poly- } \\
\text { centric } \\
\text { region? }\end{array}$} \\
\hline & \multicolumn{6}{|c|}{$\%$} & & \\
\hline & $\begin{array}{l}1976- \\
1995\end{array}$ & $\begin{array}{l}1995- \\
2014\end{array}$ & $\begin{array}{l}1976- \\
1995\end{array}$ & $\begin{array}{l}1995- \\
2014\end{array}$ & $\begin{array}{l}1976- \\
1995\end{array}$ & $\begin{array}{l}1995- \\
2014\end{array}$ & & \\
\hline Katowice & 15.0 & -1.1 & 7.1 & -11.6 & 8.9 & -9.0 & Yes & Yes \\
\hline Gdańsk & 24.3 & 32.4 & 8.6 & -0.1 & 12.8 & 9.4 & No & Yes \\
\hline Kraków & 12.2 & 18.5 & 6.3 & 2.3 & 8.1 & 7.2 & No & No \\
\hline Łódź & -3.5 & 8.5 & 3.4 & -13.3 & 2.0 & -8.9 & Yes & No \\
\hline Poznań & 20.4 & 49.1 & 10.3 & -6.1 & 13.1 & 10.1 & No & No \\
\hline Warsaw & 11.2 & 30.0 & 13.2 & 6.2 & 12.6 & 12.7 & No & No \\
\hline Wrocław & 9.9 & 23.6 & 9.8 & -1.2 & 9.9 & 5.1 & No & No \\
\hline
\end{tabular}
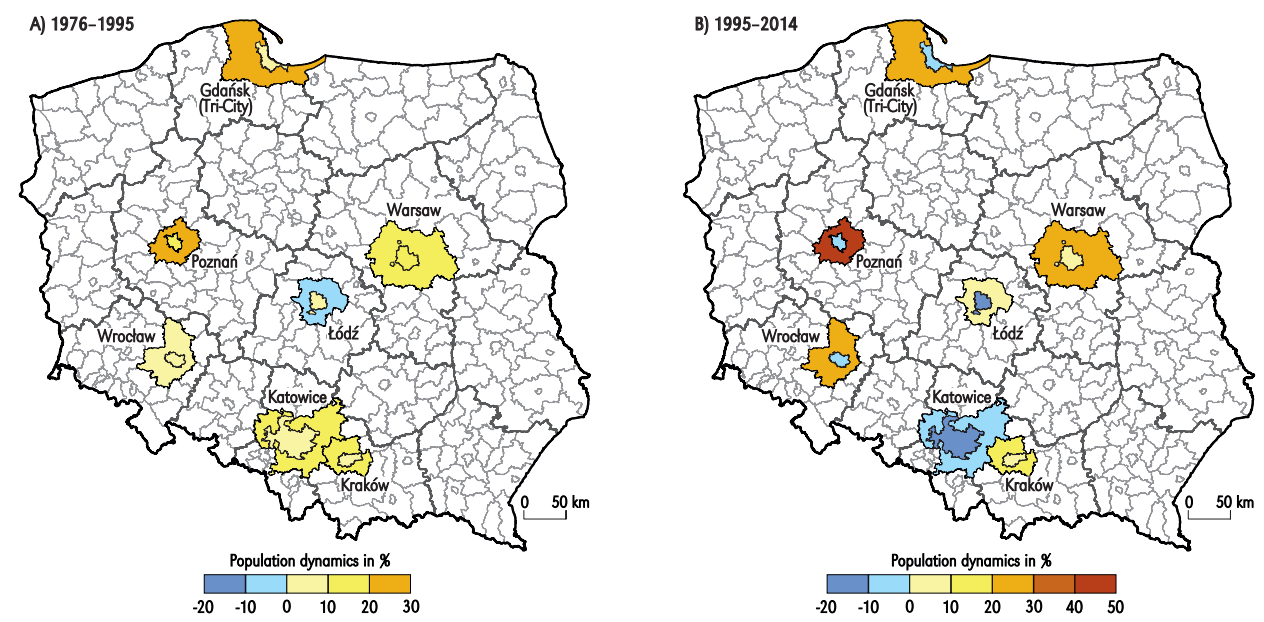

Explanations: A) presents the stage of urbanisation reached by the larger Polish agglomerations in the 1976-1995 period; picture B) the stage of suburbanisation, 1995-2014.

Figure 1. Changes of population size in Poland's larger urban agglomerations, 1976-2014

inhabitants in the two Polish agglomerations of Warsaw and Kraków.

These facts on the one hand imply relatively limited attractiveness of the suburban areas around the Katowice conurbation's core. On the other they confirm that the core there remained more attractive than the peripheral areas - a phenomenon largely explicable in terms of the social structure to that region's population, with ageing highlighted, as well as the large share of physical workers receiving relatively low salaries, plus a relatively good offer where public services are concerned. In addition, another phenomenon debilitating urban sprawl is taking place in the region, the so-called 'inner suburbanisation' to which more detailed reference is made further on in this article. These are social attributes producing an undoubted weakening of the suburbanisation process.

Analysis of the specifics to migration in this region reveals that a high percentage 


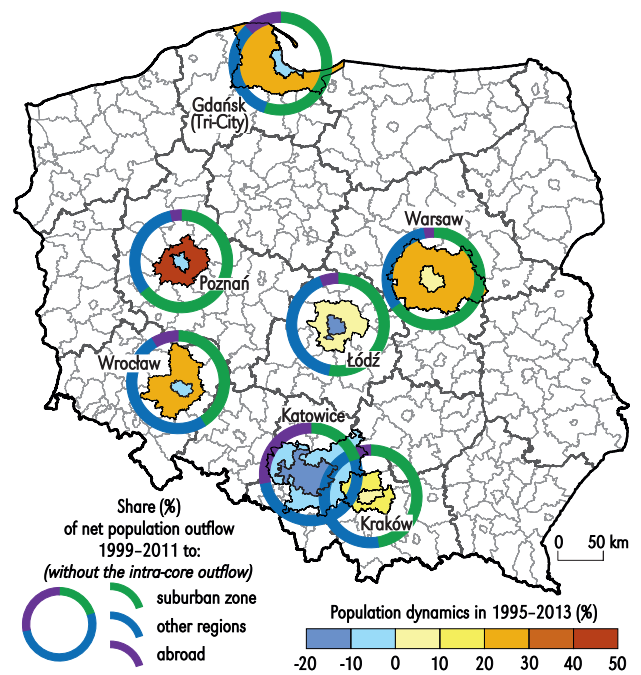

Figure 2. Types of population outflow in larger urban agglomerations in Poland

of emigration is directed beyond the urban region, with migrants who found jobs in Katowice in the 1960s and 1970s returning to their home towns (often in other regions), having obtained social benefits (a pension, including earlier retirement, or a disability pension). Since the late 1990s, migration out of Poland has also intensified (Krzysztofik et al. 2011: 13).

The second essential element of the research, underlining the role of suburbanisation around large agglomerations in more detail, concerns the rate of migration inflow from cores to suburban zones (Fig. 1).

The research indicates how the course of the suburbanisation process in the Katowice conurbation is specific, given that outflow of population to the suburban zone accounted for only about $20 \%$ of all migration from the metropolitan core. This value was about 100\% lower than the second lowest indicator noted in Poland (the $41.1 \%$ figure characterising the Wrocław agglomeration) (Fig. 2). As compared with the agglomerations of Poznan and Warsaw, the Katowice figure was lower by as much as $250 \%$. In summary, as much as $80 \%$ of the population permanently migrating beyond the core of the conurbation do so to quite different parts of the country, or abroad. International migrations in this case accounts for $27.9 \%$ of the total. In no other Polish agglomeration does this phenomenon occur to such an extent. Such a considerable share of migration going beyond the zone of impact of the Katowice conurbation combines with the structure of this outflow to emphasise quite clearly how advanced de-fragmentation and spatial dispersion of demographic structures of this urban region are.

Certain limits to the attractiveness of the suburban area around the Katowice conurbation are also indicated by the high (44\%) level of movement between the core cities. Migration between the cities at this level is up to 4 times as great as that in the suburban zone (where the comparable figure is $11.3 \%$ ). The level is only a quarter as high in the Łódź agglomeration, for example.

This kind of weakness of the suburbanisation processes ongoing in the Katowice conurbation would seem to be determined by several key factors, i.e. the locating of large industrial plants in the region's outer zone, 'competition' provided by upland and mountain landscapes just 50-80 km from Katowice, the availability of still-undeveloped areas between the two neighbouring cities, and the status of salaries 
as relatively too low to allow for the purchase of a home beyond the city limits.

A specific demographic situation of the Katowice conurbation needing to be highlighted further is that its core areas is one of the parts of Poland experiencing the most severe depopulation - in both absolute and relative terms. The 1995-2014 period saw the population of the conurbation decrease by 283 thousand, or $11 \%$ of the 1995 figure. Recent years have been characterised (CSO 2014) by the departure of 100-130 thousand people from the core of the conurbation each decade, and it seems very likely that this trend will be maintained in the near future at least. The trend for the core to depopulate will continue to be accompanied by further limited development of the suburban zone. A similar intensification of depopulation is evident only in the core of the Łódź agglomeration.

\section{Discussion}

The suburban zone is one of the key elements in the development of large urban agglomerations - both in Europe and worldwide. Studies conducted recently also confirm this hypothesis for major cities of Central Europe (Steinführer \& Haase 2007; Pichler-Milanović et al. 2007; Roose et al. 2013; Stanilov \& Sýkora 2014). It is worth emphasising how these all represent the type of metropolises centred around one large urban centre. Functional development of these cities and metropolises was based on highly accentuated services, and administration, but also, to a large extent, the industrial sector. In some metropolises, the metropolitan function was facilitated by holding capital functions or functions associated with the holding of a significant position in the global network of economic and social flows.

Irrespective of the above-mentioned group of large urban agglomerations, there are also those in which, due to deindustrialisation and regional factors, a crisis of functional identity is visible. Most of these reflect what is called urban shrinkage (Martinez-Fernandez et al. 2012; Hasse et al. 2013). Even though actions on different scales are taken to halt the outflow of population and even reurbanisation, very clear losses of population and economic potential are still being recorded. A loss of population from core areas is also present in metropolises developing strongly, though this loss is local in scale, and usually compensated for by a fairly clear increase in population in the suburban zones.

At this point, it is concluded that the scale of development of the suburbanisation phenomenon has a model dual image. In most agglomerations, the process converges with the phase of the same name understood as a stage in the evolution of a large city under the Klaassen/Paelinck and van den Berg's models. In this case, things are clear and a significant share in the local spatial redistribution of the population is being taken (Fig. 3).

In the second stage this phenomenon is of lesser importance in geographical space, and it accompanies the phase of deurbanisation. In the authors' opinion, the dual image of suburbanisation is primarily a result of the economic and social condition of the core of a metropolis. While monocentric agglomerations are characterized by 'traditional' suburbanisation, polycentric agglomerations (like the Katowice conurbation) see migration potential distracted, with some immigrants settling, not in the outer zone, but less-developed areas between two (or more) administratively adjoining towns or cities. We define this process as 'internal' suburbanisation (Lorens 2005; Runge et al. 2014).

In the case of the metropolises clearly developing or possessing important factors of functional stabilisation (e.g. capitals), suburbanisation is the consequence of the "classic sprawl of the population outside administrative boundaries of the core" to the peripheral zone. The causative agents of urban sprawl are locally strong economic functions of the metropolis (Kok 1999; Szirmai 2012; Lisowski et al. 2014).

Another view applies to such (post-) industrial regions as the Katowice conurbation. Here, the outflow of migration (size, structure) is not the result of the strength of the 


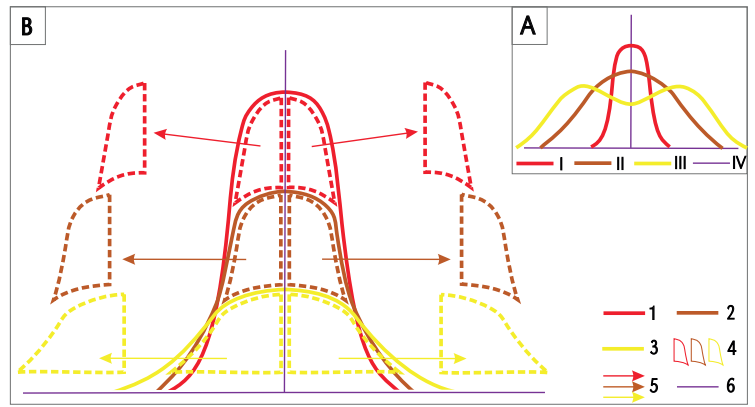

Explanations: A: I - stage of urbanisation, II - stage of suburbanisation, III - stage of deurbanisation,

IV - axes. The stage of reurbanisation has not been taken into account in the model.

B: 1, 2, 3 - spatio-temporal stages of urban shrinkage and deurbanisation, 4 - population migrating beyond the urban system in question, 5 - directions to redistribution of the population beyond the urban system in question, 6 - axes.

Figure 3. The development of large cities after Klaassen/Paelinck (A) and van den Berg, and population redistribution in the postindustrial Katowice conurbation (B)

Source: Kantor-Pietraga 2014: 44, 45.

region, but of its problems and limitations, or as Dostál and Hampl (2008: 44) defined it - "urbanisation as a re-homogenising process". Suburbia are created not due to the 'overflow' of demographic potential, but rather to its 'spillage'. This is due to the relative weakness of the local socio-economic system. Larger suburban settlements develop in some areas, as a result, not of the strength of the metropolitan core, but of the severity of its problems. Hence, many potential migrants with the necessary professional and financial means decide to settle in a region completely different from the one proving less and less able to attract them.

Here, suburbanisation zones are not shaped the way they are in pro-development agglomerations - as compact concentrated buffer zones, with decreasing potential with growing distance from the boundaries of the core. rather, the polycentric shrinking regions like the Katowice conurbation reveal a spotarea and non-zone model of suburbanisation, meaning that new suburban areas do not form compact buffer zones of the core, but are often isolated enclaves among hitherto-existing settlements. The occurrence of large, sprawling but compact areas of suburbanisation is less frequent. Here also, the suburbanisation has no features of zoning, and often fails to develop in the vicinity of the core at all, being rather present in substantial complexes located $15-30 \mathrm{~km}$ away from the core's boundaries.

The specific model of suburbanisation applying in the Katowice conurbation therefore contrasts with the phenomena observed in other large Polish cities (Zborowski et al. 2012). Factors shaping a specific path of spatial suburbanisation relate to socioeconomic regression (deindustrialization and urban shrinkage), as well as urban polycentricity (with about 20 towns and cities in the core located in close proximity to one another and having a common administrative boundary). These elements may also be applied to two other agglomerations in Poland - of Gdańsk and Łódź. The Gdańsk agglomeration (Tri-City) is also of the polycentric type, with exposed particular role being played by the two major cities of Gdańsk and Gdynia. This agglomeration is as highly populated as the Katowice conurbation, but (despite its name) consists of only two major cities.

The second example involves the (post-) industrial agglomeration of Łódź, whose core is characterised by marked demographic, economic and social regress. The process of urban 
shrinkage has been especially evident in Łódź, which lost 130 thousand inhabitants in the years 1990-2013 (with a decline in population from 840 to 710 thousand). After the Katowice conurbation, the Łódź agglomeration is Poland's most glaring example of a (post-) industrial agglomeration shrinking and being affected by a profound transformation of socio-economic structures (Marcińczak 2012).

The question for consideration here therefore concerns whether the limits to the development of suburbanisation in the Katowice conurbation are created by the polycentricity of the region and its shrinkage and regress. The facts presented here support this contention. Other than as regards the two previously mentioned elements conditioning development, i.e. polycentricity and post-industrialism, the Katowice conurbation does not differ fundamentally from other agglomerations in Poland.

Interesting reference may be made to the example of the post-industrial agglomeration of Ostrava (Czech Republic), whose origins are similar to those of the Katowice conurbation (in coal mining and metallurgy). Here, the suburbanisation zone is quite clear and encompasses, not only formally, rural municipalities around the core of the agglomeration. Population growth and new built-up areas are also visible in most districts of Ostrava (Rumpel \& Slach 2012). It should be emphasised though that the Ostrava agglomeration is closer in terms of its structure to the Łódź agglomeration than the Katowice conurbation.

The thesis concerning the specific model of demographic transformation in the polycentric post-industrial conurbations is confirmed by the example of the Ruhrgebiet and Saarland, in which both the phenomenon of suburbanisation and suburbanisation as a phase in the evolution of large agglomerations are similar to their counterparts observed in the Katowice conurbation (Blotevogel \& Schickhof 1986; Stiftung Demographischer Wegweiser 2006; Hänsgen et al. 2010).

When analysing the current demographic development of the Katowice conurbation in relation to van den Berg's model, there is doubt as to whether all large cities may, following the stage of relative centralisation, enter one entailing absolute decentralisation and scattering? Or maybe, in some cases, instead of the scattering of potential of some metropolises, we will have to experience its permanent recourse? And finally, consideration should be given as to whether, in the transformation of urban regions, we will have to deal with the post-suburban reality everywhere (Phelps \& Wu 2011). This is all the more true given that, in the discussed conurbation, the scattering of demographic potential relies, not on population movements into the suburban zone, but on transfers to more remote regions, often several hundred or even several thousand kilometres away.

\section{Conclusions}

The above discussion leads to the conclusion that the geographical individuality of the Katowice conurbation results from a combination of the two attributes of post-functionalism and polycentricity, while also reflecting the relatively large area across which these phenomena are in operation. On the other hand, examples provided by other major conurbations in Poland indicate that a decline in importance or lack - of the above attributes is associated with a rather 'traditional' distribution of suburbanisation processes.

This further suggests that, notwithstanding their undoubted validity as regards monocentric agglomerations characterised by a diverse economic base (with an exposed role of services), the models of metropolitan development presented by Klaassen and Paelinck (1979), and van den Berg et al. (1982), can only be thought to offer an initial understanding of what takes place in highly-industrialised, polycentric urban conurbations.

Key deviations from the above models presenting the stages to the evolution of a large city (via urbanisation, suburbanisation, de-urbanisation and re-urbanisation) relate to:

- a limited role for suburbanisation and the discontinuous distribution of the phenomenon across geographical space, 
- a direct transition from the urbanisation stage to that of de-urbanisation and (or) urban shrinkage,

- the phenomenon of 'inner suburbanisation'. In both cases, the immediate cause of the phenomena observed in Katowice is a quite complex process describable in terms of the (post-) industrial conurbation being a strong region on account of its density of population, but at the same time being too weak to maintain its potential. A key consequence of that is that demographic loss is a feature, not only of the core of the conurbation, but also of its suburban area - a phenomenon not to be noted in other large Polish or Central European agglomerations.

This case can be looked at from another point of view, given that here is an extensive urban region consisting of a dozen towns of 50-200 thousand inhabitants, of poorly marked and distributed metropolitan functions, and a partly traditional economic profile. Such an area cannot be said to attract people, but rather - in a sense - to repel them. This reflects the specialised functions here being at a much higher level than in prodevelopment monocentric urban areas. Spatial redistribution of the population does not rely on movement to suburbia, but rather has the population migrating to regions and metropolises far (sometimes very far) from the core. Cities of 100 thousand inhabitants (even several of them distributed across a conurbation), do not form such a strong metropolitan core as even a single city of 500 thousand with highly concentrated metropolitan functions at its centre.

The non-significant force of attraction (revealed through the predominant migratory outflow characterising every town or city in the Katowice conurbation) also contributes to a steady decline in rental prices payable in the core of the conurbation. This phenomenon is also promoted by a large supply of brownfield investment areas and the existence of available greenfield investment zones within the core. Via the phenomenon of 'inner suburbanisation', these spatial attributes also reduce the exodus to suburbia markedly.

This is also facilitated by the fact that part of the population wishing to leave a city may move to one of several other neighbouring cities spread across an area of over $1000 \mathrm{~km}^{2}$. This is not possible in the case of monocentric agglomerations, and even the core-city area outside Warsaw (over $500 \mathrm{~km}^{2}$ ) does not exceed $200-300 \mathrm{~km}^{2}$. More opportunities in this case are offered by the suburban zone, whose undeniable attribute is lower prices for land and houses. However, in the post-industrial conurbation, land prices do not differ significantly between the core and suburbia.

Overall, where are the noted demographic changes leading this region? Both the demographic forecasts and the phenomena observed in the analysed conurbation point to a strengthening of existing phenomena, i.e. a continued, relatively limited phenomenon of suburbanisation, quite clear depopulation of city centres and numerous block housingestates here, and a continuing tendency for people to migrate beyond the suburban zone. Actions taken via urban and regional policies may at most slow these phenomena a little.

\section{Acknowledgements}

This work gained the financial support of the Polish National Science Centre (Decision No. DEC-2014/13/N/HS4/03575) and the Department of Economic Geography, Faculty of Earth Science, University of Silesia, Sosnowiec, Poland.

\section{Editors' note:}

Unless otherwise stated, the sources of tables and figures are the authors', on the basis of their own research. 
Is the suburbanisation stage always important in the transformation of large urban...

\section{References}

BAJMOCY P., 2012. Suburbanisation and suburban regions in Hungary after 1990 [in:] T. Csapó, A. Balogh (eds.), Development of the settlement network in the Central European countries: Past, present, and future, Berlin, Heidelberg: SpringerVerlag, pp. 207-221.

BLOtevogell H.H., SCHICKHOfF I., 1986. Suburbanisation in densely populated areas with several foci: The example of the Rhine-Ruhr industrial area [in:] G. Heinritz, E. Lichtenberger (eds.), The take-off of suburbia and the crisis of the inner city: Proceedings of the International Symposium in Munich and Vienna 1984, Stuttgart: Franz Steiner Verlag, pp. 74-98.

Brade I., Smigel C., Kovács Z., 2009. Suburban residential development in post-socialist urban regions: The case of Moscow, Sofia, and Budapest [in:] H. Kilper (ed.), New disparities in spatial development in Europe, Berlin, Heidelberg: Springer-Verlag, pp. 79-104.

CiRTAutas M., 2013. Urban sprawl of major cities in the Baltic states. Scientific Journal of Riga Technical University, ser.10, Architecture and Urban Planning, pp. 72-79.

Couch C., Leontidou L., Petschel-Held G. (eds.), 2007. Urban sprawl in Europe. Landscapes: Land-use change and policy. Oxford: Blackwell Publishing.

CSO, 1990. Statistical Yearbook of Poland, 1990. Number of vehicles in Poland, 1989. Warsaw: Central Statistical Office.

CSO, 2014. Population Projection 2014-2050. Warsaw: Central Statistical Office.

CSO, 2015. Statistical Yearbook of Poland, 2015. Number of vehicles in Poland, 2014. Warsaw: Central Statistical Office.

Dostál P., Hampl M., 2008. Development of national settlement systems in the industrial and post-industrial areas: A general discussion and the case of the Czech Republic [in:] W. Strubelt, G. Gorzelak (eds.), City and Regions: Papers in honour of Jiř́ Musil, Leverkusen Opladen: Budrich Uni Press, pp. 43-54.

EU, 2006. Urban sprawl in Europe: The ignored challenge. European Commission, Luxembourg, Copenhagen: Joint Research Centre, European Environment Agency.
GANS P., 2000. Urban population change in large cities in Germany, 1980-94. Urban Studies, vol. 37, no. 9, pp. 1497-1512.

Haase A., Bernt M., Grossman K., Mykhnenko V., 2013. Varieties of shrinkage in European cities. European Urban and Regional Studies, vol. 23, no. 1, pp 86-102.

Hänsgen D., Lenz S., Tzschaschel S., 2010. Deutschlandatlas: Unser Land in 200 thematischen Karten. Darmstadt: WBG.

HoEkVELD J.J., 2015. Spatial differentiation of population development in a declining region: The case of Saarland. Geografiska Annaler: Series B. Human Geography, vol. 97, no. 1, pp. 47-68.

KabisCH N., HaASE D., 2011. Diversifying European agglomerations: Evidence of urban population trends for the 21st century. Population, Space and Place, vol. 17, no. 3, pp. 236-253.

Kabisch N., HaASe D., HaASe A., 2012. Urban population development in Europe, 1991-2008: The examples of Poland and the UK. International Journal of Urban and Regional Research, vol. 36, no. 6, pp. 1326-1348.

Kantor-Pietraga I., 2014. Systematyka procesu depopulacji miast na obszarze Polski od XIX do XXI wieku. Katowice: Wydawnictwo Uniwersytetu Śląskiego.

Klaassen L.H., Palinck J.H.P., 1979. The future of large towns. Environment and Planning A, vol. 11, no. 10, pp. 1095-1104.

KoK H., 1999. Migration from the city to the countryside in Hungary and Poland. GeoJournal, vol. 49, no. 1, pp. 53-62.

KorCelLi P., 1972. Urban spatial growth. A wavelike approach. Geographia Polonica, vol. 24, pp. 45-55.

KRIŠJANe Z., BerZINŠ M., 2012. Post-socialist urban trends: New patterns and motivations for migration in the suburban areas of Riga, Latvia. Urban Studies, vol. 49, no. 2, pp. 289-306.

Krzysztofik R., Runge J., Kantor-Pietraga I., 2011. Paths of shrinkage in the Katowice Conurbation. Case studies of Bytom and Sosnowiec cities. Sosnowiec: Wydział Nauk o Ziemi Uniwersytetu Śląskiego.

LeetmaA K., Tammaru T., 2007. Suburbanization in countries in transition: Destinations of suburbanizers in the Tallinn metropolitan area. Geografiska Annaler: Series B. Human Geography, vol. 89 , no. 2, pp. 127-146. 
LIsowski A., ManteY D., WiLK W., 2014. Lessons From Warsaw: The lack of coordinated planning and its impact on urban sprawl [in:] K. Stanilov, L. Sýkora (eds.), Confronting suburbanization: Urban decentralization in postsocialist Central and Eastern Europe. Chichester: John Wiley \& Sons, pp. 225-255.

LORENS P., 2005. Suburbanizacja $w$ procesie rozwoju miasta postsocjalistycznego [in:] P. Lorens (ed.), Problem suburbanizacji, Biblioteka Urbanisty, 7, Warszawa: Urbanista, pp. 33-44.

MaIK W. (ed.), 2009. Aglomeracje miejskie w Polsce na przełomie XX i XXI wieku. Problemy rozwoju, przeksztalceń strukturalnych i funkcjonowania. Bydgoszcz: Wydawnictwo Uczelniane Wyższej Szkoły Gospodarki.

MARCIŃCZAK S., 2012. The evolution of spatial patterns of residential segregation in Central European Cities: The Łódź Functional Urban Region from mature socialism to mature post-socialism. Cities, vol. 29, no. 5, pp. 300-309.

Martinez-Fernandez C., Audirac I., Fol S., CunNINGHAM-SABOT E., 2012. Shrinking Cities: Urban Challenges of Globalization. International Journal of Urban and Regional Research, vol. 36, no. 2, pp. 213-225.

MusIL J., 1993. Changing urban systems in postcommunist societies in Central Europe: Analysis and prediction, Urban Studies, vol. 30, no. 6, pp. 899-905.

MykHnenKo V., TUROK I., 2008. East European cities - Patterns of growth and decline, 1960-2005. International Planning Studies, vol. 13, no. 4, pp. 311-342.

Nicolaides B.M., Wiese A. (eds.), 2006. The suburb reader. New York, Abingdon: Routledge.

NuISSL H., RINK D., 2005. The "production" of urban sprawl in eastern Germany as a phenomenon of post-socialist transformation. Cities, vol. 22, no. 2, pp. 123-134.

OUŘENIČEK M., 2007. Differential suburban development in the Prague Urban Region. Geografiska Annaler: Series B. Human Geography, vol. 89, no. 2, pp. 111-126.

PARYSEK J.J., 2005. Miasta polskie na przełomie XX iXXI wieku. Rozwój i przekształcenia strukturalne. Poznań: Bogucki Wydawnictwo Naukowe.

Phelps N.A., Wu F. (eds.), 2011. International perspectives on suburbanization: A post-suburban
World? Basingstoke, New York: Palgrave Macmillan.

Pichler-Milanovič N., Gutry-KoryCKA M., RINK D., 2007. Sprawl in the post-socialist city: The changing economic and institutional context of Central and Eastern European cities [in:] C. Couch, L. Leontidou, G. Petschel-Held (eds.), Urban sprawl in Europe. Landscapes, Land-Use Change \& Policy, Oxford: Blackwell Publishing, pp. 102-135.

Ravetz J., Fertner C., Nielsen T.S., 2013. The dynamics of peri-urbanization [in:] K. Nilsson, S. Pauleit, S. Bell, C. Aalbers, T.S. Nielsen (eds.), Peri-urban futures: Scenarios and models for land use change in Europe. Berlin, Heidelberg: SpringerVerlag, pp. 13-44.

Roose A., Kull A., Gauk M., Tali T., 2013. Land use policy shocks in the post-communist urban fringe: A case study of Estonia. Land Use Policy, vol. 30, no. 1, pp. 76-83.

Rubiera Morollón F., Gonzáles Marroquin V.M., Pérez Rivero J.L., 2016. Urban sprawl in Spain: differences among cities and causes. European Planning Studies, vol. 24, no. 1, pp. 207-226.

Rumpel P., SlaCH O., 2012. Je Ostrava "smrštujicím se městem"? Sociologický časopis, vol. 48, no. 5, pp. 859-878.

Runge J., Krzysztofik R., Kantor-Pietraga I., SpórNA T., 2011, Characteristic Features of Urbanization in the Area of Silesian Province (Poland) at the Beginning of 21st Century, Romanian Sociology (Sociologie Românească), vol. 9, no. 3, pp. 56-66.

Runge J., Kantor-Pietraga I., Krzysztofik R., RUnGe A., 2014. Model urbanizacji złożonych układów osadniczych w świetle procesu kurczenia się miast w Polsce - próba analizy krytycznej [in:] T. Stryjakiewicz (ed.), Kurczenie się miast w Europie Środkowo-Wschodniej, Poznań: Bogucki Wydawnictwo Naukowe, pp. 115-125.

Sailer-Fliege U., 1999. Characteristics of postsocialist urban transformation in East Central Europe. GeoJournal, vol. 49, no. 1, pp. 7-16.

Salvati L., Carlucci M., 2014. In-between stability and subtle changes: Urban growth, population structure, and the city life cycle in Rome. Population, Space and Place, Early View.

SCHMIDT S., 2011. Sprawl without growth in Eastern Germany. Urban Geography, vol. 32, no. 1, pp. 105-128. 
Schmidt S., Fina S., Ssiedentop S., 2015. Post-socialist sprawl: A cross-country comparison. European Planning Studies, vol. 23, no. 7, pp. 1357-1380.

Scom A.J., 2001. Globalization and the rise of cityregions. European Planning Studies, vol. 9, no. 7, pp. 813-826.

ŚLESZYŃSKI P., 2006. Demograficzny wymiar procesów suburbanizacji w Polsce po 1989 roku [in:] S. Kozłowski (ed.), Żywiołowe rozprzestrzenianie się miast: Narastajacy problem aglomeracji miejskich w Polsce. Studia nad zrównoważonym rozwojem, vol. 2, Białystok-Lublin-Warszawa: Wydział Ekonomia i Środowisko, pp. 105-123.

SokOŁOWskı D., 2006. Funkcje centralne i hierarchia funkcjonalna miast w Polsce. Toruń: Wydawnictwo Uniwersytetu Mikołaja Kopernika.

Stanilov K., SÝkORa L. (eds.), 2014, Confronting suburbanization: Urban decentralization in postsocialist Central and Eastern Europe. Chichester: Wiley-Blackwell.

Steinführer A., HaAse A., 2007. Demographic change as future challenge for cities in East Central Europe. Geografiska Annaler: Series B. Human Geography, vol. 89, no. 2, pp. 183-195.

Stiftung Demographischer Wegweiser, 2006. Wegweiser Demographischer Wandel 2020. Analysen und Handlungkonzepte für Städte und Gemeinden. Bielefeld: Bertelsmann Stiftung Verlag.
SÝKORA L., BouZAROVSKI S., 2012. Multiple transformations: Conceptualising the post-communist urban transition. Urban Studies, vol. 49, no. 1, pp. 43-60.

SÝKORA L., OUŘEenIČEK M., 2007. Sprawling post-communist metropolis: Commercial and residential suburbanization in Prague and Brno, the Czech Republic [in:] E. Razin, M. Dijst, C. Vázquez (eds.), Employment deconcentration in European Metropolitan Areas: Market forces versus planning regulations, Dordrecht: Springer, pp. 209-233.

SzIRMAI V., 2012. Urban sprawl in Europe. Regional Statistics, no. 01, pp. 129-148.

Turok I., Mykhnenko V., 2007. The trajectories of European cities, 1960-2005. Cities, vol. 24, no. 3, pp. 165-182.

van den Berg L., Drewett R., KlaAssen L.H., Rossi A., VIJWERBERG C.H.T., 1982. Urban Europe: A study of growth and decline. Oxford: Pergamon Press.

YE L., WU A.M., 2014. Urbanization, land development, and land financing: Evidence from Chinese cities. Journal of Urban Affairs, vol. 36, no. 1, pp. 354-368.

ZBOROWSKI A., SOJA M., ŁobOdZIŃSKA A., 2012. Population trends in Polish cities - stagnation, depopulation or shrinkage? Prace Geograficzne, vol. 130, Kraków: Instytut Geografii i Gospodarki Przestrzennej UJ, pp. 7-28.
(C) Robert Krzysztofik - Iwona Kantor-Pietraga • Anna Runge - Tomasz Spórna

(C) Geographia Polonica

(C) Institute of Geography and Spatial Organization Polish Academy of Sciences • Warsaw • 2017
Article first received • October 2015

Article accepted • December 2016 